\title{
Freedom in the Face of Nicaragua's Hybrid Carceral System
}

\author{
Julienne Weegels, CEDLA, University of Amsterdam
}

\begin{abstract}
Drawing on extensive prisons research and sustained contact with (former) prisoners in Nicaragua, this article explores three former prisoners' post-release trajectories. In the face of a hybrid state that manifests as both a legal penal state and an extralegal system of powers, colloquially referred to as el Sistema (the System), and to the backdrop of a (d)evolving political context, I argue for an understanding of the 'tightness' of post-release life by conceptualizing the Sistema's transcarceral grip. Former prisoners deal with this grip in different ways, ranging from self-censorship to the taking of 'delinquent freedoms'. A detailed understanding of this grip can help pinpoint how carceral logics are mobilized outside prison in Nicaragua and how its carceral state expands through not only legal but also extralegal means.
\end{abstract}

Keywords: carceral state, confinement, drug trafficking, extralegality, hybrid state, post-release life, reimprisonment

'What you should never do is look back. If you do, the galería (cellblock) will call you, the whole block will call you.' Bobby's ${ }^{1}$ eyes widen with warning. At age twentythree he has already spent the previous six years in and out of La Modelo on four separate sentences. 'You shouldn't take anything with you,' he continues, 'what you have, you should leave it to those with long sentences. ... No thinking "but that's mine", no, nothing! You leave and move forward, keep moving forward until you get to the door. ... You can leave tranquilo (calmly). All that matters is that you don't look back. ... [Think of] a dark alley that you'll pass through, you'll pass by twelve galerías; of all these twelve galerías you should never look back to the end. If you do, they'll call you from the end. I didn't believe that was true, but I looked back, and they called me'

'How do they call you?' I ask.

'Suddenly, Bobby explains. 'You leave, you can be in the neighbourhood, tranquilo, then some problem [i.e. crime] will blow up in your face that you maybe didn't even commit, and then you'll be back in the Sistema again.... There, the others, the prisoners, will tell you "look, you see that you came back, and I told you that you 
shouldn't look back." Perhaps it's the clothes I wore the day I got out and I put them back on.... Bobby raises his hands. '[The thing is that] the galería calls you.' He sits back.

'So the clothes you wear, outside [upon release]...?'

'You have to burn them,' he answers sternly. 'Burn them because it's una sal (bad luck)'.

According to Bobby, the haunting grip of the Nicaraguan prison system is extended through the belongings one takes along from prison, in the very clothes one wears when leaving. It is manifested in the 'bad luck' that follows former prisoners into their post-release lives if they do not (literally) burn all connections to the carceral space. Significantly, prison's transcarceral grip is articulated through this popular myth. Building on Anke Allspach (2010) and Dominique Moran's (2014) understanding of the re-articulation of confinement in 'transcarceral spaces' - through the extension of the prison space beyond its physical environment by way of remaining prison identifiers and stigma - I here propose a melding of the notion of the transcarceral space with Ben Crewe's (2011) conceptualization of prison's 'grip'. I believe that by drawing attention to prison's transcarceral grip we might understand how former prisoners remain affected by their imprisonment through the 'tightness' that post-release life acquires in the face of continued communitarian surveillance and state intervention. As authorities keep former prisoners en la mira (in view), prison's grip is extended beyond its walls, holding former prisoners tightly as they seek to rebuild their lives on the outside. Importantly, this points both to the expansion of Nicaragua's carceral state and to its hybrid enactment.

After exploring current debates on carceral expansion, governance and the hybrid state in relation to Nicaragua's Sistema, I explore the way in which the transcarceral grip is articulated through post-release stigmas, which are deemed to give the former prisoner color (a delinquent stigma or bad reputation). This process ties into the different ways in which the Sistema's transcarceral grip is dealt with by former prisoners, leading to three divergent post-release trajectories. The first is characterized by an attempt on the part of former prisoners to retreat from the Sistema entirely by disappearing out of view. The second, similar to the first, is distinguished by the practice of restraint (avoiding color) in order to remain physically free and as far away from the Sistema's grip as possible, without necessarily leaving one's 'old' life behind. Here, self-censorship becomes a tool to reverse prison's mortifying effects and to escape the transcarceral grip. Yet as former prisoners struggle to (re)build a straight life in the face of stigma and the transcarceral grip, some engage in a refusal of the persistent surveillance of both authorities and society over them. This constitutes the third trajectory, which is led by the practice of refusal (embracing color) through the taking of 'delinquent freedoms' that reject the imposition of a constrained freedom (Rosas 2012). In this sense, when 'doing freedom' (Ugelvik 2014) on the outside, former prisoners might in fact become involved in activities on or across the line of the legal, which brings them closer to the possibility of reimprisonment. Simultaneously, however, the taking of these 
freedoms allows them to reject the (hybrid) state and its confining capacities - even if temporarily.

Having said this, just as inside prison, former prisoners may be engaged in both law-abiding and law-breaking activities - that is, in both self-censorship and refusal. They may be highly focused on their straight life but still engage in moments of release through means, activities or substances pertaining to the delinquent realm. Conversely, they may be fully engaged in the delinquent realm yet only partially project this. Trying to make sense of the intimacy and confusion of prisoners' post-release experiences, I here seek to provide a close examination of the ways in which prison's transcarceral grip redefines confinement beyond the prison's walls. I do this based on thirty-one months of ethnographic research conducted with prisoners and former prisoners between 2009 and 2016, ${ }^{2}$ which included sustained interaction with my research collaborators as they left prison, both through follow-up visits and a former prisoner radio show that I set up with a number of them in a joint attempt to 'destigmatize' the prison experience.

\section{Hybrid states, carceral expansion and the Nicaraguan Sistema}

Over the past years, ethnographic research on the urban margins has stressed the impact of repressive policing tactics and its entanglement with the (re)production of social inequality, both in the form of producing divergent modalities of citizenship (e.g. Fassin 2013; Goffman 2014; Goldstein 2012; Jensen 2010) and of expressing the state's necropolitical power (e.g. Denyer Willis 2015; Gledhill 2015; Van Stapele 2016). Similarly, such research has sought to grapple with the expansion of criminal justice and prison systems, especially in the face of mass incarceration and neoliberalist policy development (e.g. Iturralde 2016; Sim 2009; Wacquant 2009). At the same time, much attention has been dedicated to understanding the interaction of the state with non-state (armed) actors in disputes both over the (legitimate) control over territory, service/security provision and illegal markets in Latin Americanist debates on (the entanglement of) state and criminal governance (e.g. Arias 2006; Holston 2008; Huggins 1991; Jaffe 2013; Penglase 2014). Related to this, a breadth of qualitative research conducted in Latin America's prison systems has delved into the everyday governance of these spaces (including, perhaps most importantly, through self- and co-governance; e.g. Antillano 2017; Biondi 2016; Carter 2017; Darke and Garces 2017; Macaulay 2013; Weegels 2019).

Virtually disconnected from this, mainstream criminological research on post-release life has continued to centre around the question of deterrence and desistance, while more critical and transdisciplinary criminological debates have been more attuned to the ways in which imprisonment impinges itself on particular kinds of populations in particular ways, and how this is related to social stigma and the expansion of carceral logics beyond prison (e.g. Allspach 2010; Maruna 2001; Moran 2014). In particular, the latter discussion has led to a consideration of 'transcarceral spaces' as pivotal for the (re)production of carceral logics outside prison (Allspach 2010; Moran 2014). Bringing this notion into dialogue with Ben 
Crewe's conceptualization of prison's 'penal grip' - that is, a lighter but tighter' hold over prisoners' lives inside prison that 'turns the self into a vehicle of power rather than a place of last refuge' (2011: 524) - and taking note of the connection of this debate to earlier work on social control and governance (Foucault [1975] 1991; Garland 1997), I propose the notion of a transcarceral grip to better understand how carceral logics (surveillance, stigma, tightness, control and refusal) follow former prisoners into their post-release lives. Importantly, such a focus allows me to bring the transcarceral grip into conversation with the above-mentioned debates on governance and carceral expansion. Moreover, a close examination of the qualities of this grip points to modalities of carceral expansion through not only legal but also extralegal means.

In Nicaragua, (former) prisoners colloquially refer to the prison system as $e l$ Sistema (the System). Yet this reference does not just include the prison system; it is also held to represent an extralegal system of state power melded with political and criminal power, where mutual entanglements of (para)state and (para)criminal governance manifest in different configurations of state and non-state power on the ground (akin to the 'criminal governance networks' described by Arias [2006], and the 'hybrid state' described by Jaffe [2013]). As such, the Sistema exceeds the prison system and the judiciary, and includes the full relational system of state and nonstate political actors that are able to (legitimately) exert their power over and through the state apparatus, including its executive, legislative and governing institutions. In this way, the Sistema produces carceral subjects that can be acted upon by the penal state's legal framework (Garland 2013), but also by its extralegal framework, which is composed of a series of extralegal and illegal connections and practices. In Nicaragua, these practices have come to characterize the criminal justice system to such an extent that law enforcement on the part of the Sistema might best be understood as an expanding hybrid carceral system that emanates from a highly politicized (Sandinista) state and its institutional framework, which was nonetheless largely veiled by its capacity to make its extralegal operations appear legitimate. ${ }^{3}$

Yet state authorities appear not as concerned with total control over every aspect of prison (as is apparent through their involvement of co-governors; see Weegels 2017, 2019), but rather for prison to serve as a mirror for the totalizing effects of the Sandinista state over society at large. Interestingly, the Nicaraguan Sistema appears to point to a simultaneous inversion and expansion of the totalizing effects that Goffman ([1961] 1991) and Foucault ([1975] 1991) held the prison system (and through it the state) to have. I say 'totalizing effects' because in spite of the relentless impingement of the state upon its subjects, it still relies on a legitimation and sharing of its 'total control' to effectuate its disciplinary power. While Foucault points to a similar societal and disciplinary function of the prison, followed by Wacquant who extrapolates and conceptualizes from this point of departure the 'carceral state' and 'carceral continuum' (popularly known as the 'ghetto to prison pipeline'), ${ }^{4}$ the modality of control and disciplinary power that they suggest hinges on a transposition of the carceral onto the urban. I hold, however, that this transposition is not total, but partial, affective and performative. Moreover, it is political 
and largely able to 'viably and normatively coexist territorially with more localised non-state forms of social regulation' (Rodgers 2006: 317) through the involvement of particular moral discourses and particular carceral subjects in a continued mesh of legal and extralegal (state) governance practices. In this way, we can partially dislocate Wacquant's continuum from specific geographical localities and instead extend (or narrow) it to those people who are acted upon by the Sistema. That is, to those affected by its transcarceral grip. In the following three sections I address first stigma (color) and self-censorship, then restraint, and finally refusal as the structural condition and three interrelated practices that former prisoners engage in to avert the Sistema's grip while also considering situations that place them squarely within it.

\section{Between sticking out and disappearing: of color and dodging the Sistema's gaze}

(Former) prisoners are well aware that they leave prison colorados (stigmatized) and fichados (marked with a ficha, a police record or informal police tab). While these states of being refer to the presence of stigma, they also point to an unequivocal presence en la mira of the authorities. As such, they are conditions against which former prisoners adapt their movement, appearance and narratives. Seeking to disappear from view, their work to avoid color often took on quite literal forms: Beto hid his convict status from his employers, just like all others attempting to hold down a job; Wilfredo would not dare tell his schoolmates that he was once convicted and could not return to his town of birth; Wiz no longer partied on the street with his buddies, keeping to the house instead. Their perceived color, then, influenced these young men's attempted re-entry. Alluding to his color, Bobby noted that he felt like he could not leave his neighbourhood, because he felt 'looked at' the moment he stepped 'into society'. In fact, his color followed him from the prison to the street to such an extent that he even counted the months he spent in between sentences outside prison as part of his time inside the Sistema:

I've done about seven years for the Sistema, counting some of the months I was out maybe as in, because when I would be out on the street everyone would look at me like I was dangerous (chiva). And I wasn't dangerous, I was normal. ... I would say hi to people because they would look at me [signalling the tattoos on his arm], like 'what's up badass'. [But] I'm not a dangerous man, I'm a good person. ... Still my [criminal] record and the tattoos [most visible on his full left arm and right hand] make it very hard to convince an employer to hire me. ${ }^{5}$

Bobby's account indicates how the delinquent and prisoner stigma envelop the former prisoner and hold him tightly. This situation is magnified on the local community level by the entanglement of policing with politics, which produces different modalities of (communal) surveillance. Prisoners are frequently granted a conditional early release (a form of parole) that includes months or years signing (firmar) with the judge on a weekly, monthly or bi-monthly basis. The conditions 
for this release are morally underpinned and surveilled in the community: no congregating in public spaces, no public drinking, prohibited access to bars, clubs and snooker halls, and clearly no run-ins with the law. In order to enforce these prohibitions, both police and barrio residents who may inform them ${ }^{6}$ participate in the surveillance of known fichados (people with a record). This mesh of police and communal surveillance produces an 'eye' on former prisoners that is significantly larger than if the police were on their own. Mirroring prison, these communal eyes and ears are frequently referred to by former prisoners as orejas or sapos (snitches). Yet significantly different from prison is that fichados are largely isolated in their barrios, towns and villages of residence. Even those residents who engage in crime frequently seek to dissociate from former prisoners, as they are believed to attract the unwelcome attention of the law. This explains why former prisoners, rather than readily discussing their prison time, largely attempted to avert both communal and police surveillance by blending in and staying out of view.

It was telling of the risks and caution enveloping post-release life that it was difficult for me to find former prisoners whom I had not previously worked with inside prison willing to discuss their prison experiences and post-release life with me. Therefore, most of the experiences reflected here concern those of former prisoners who were also my research collaborators inside prison. Yet even for prisoners whom I knew for years inside prison, following them back to the outside was never easy. I would often not see the homes or meet the families of those collaborators who sought to hide their ex-convict status as I effectively represented a link to prison. Instead we met at busy parks, lunchrooms and diners, talked on buses or in the backseat of private vehicles as we moved to more official sites together, like the judicial complex or the radio station where I co-hosted a live talk show with other former prisoners (about prisoner rights and against former prisoner stigmatization). ${ }^{7}$ Even for former prisoners who were (relatively) open about their status, places where the police might be present in an effective capacity, or places where other former prisoners could be present, remained largely out of the question. As they put it, nobody wanted to 'agarrar color de puro aire' - have someone else's color rub off on them 'for nothing'.

Importantly, prisoners' attempts to insulate themselves against the transcarceral grip prior to release, by trying to leave prison as lightly packed as possible, as Bobby explained in the vignette at the beginning of this article, were a central ritual to avert color. By 'not looking back' and leaving behind belongings (gifting them to their cellmates), young men leaving prison attempt to free themselves of the 'bad luck' that could follow them out of prison and cause their reimprisonment. Bobby was not the only person to elicit this ritual. Many former prisoners repeated the same belief - even if they had already been imprisoned multiple times. They maintained that they would leave their belongings with their cellmates and burn the clothes they were wearing when they got out. Interestingly, by leaving behind their belongings without looking back, they attempted not only to secure their release from the legal penal system, but also to absolve their debt to the hybrid Sistema, including the prisoner hierarchy. 'After all', Araña noted, 'you never know if you might be back.' 
There were a number of prisoners who sought to break with prison entirely, however, most of whom I would never be able to meet on the outside. ${ }^{8}$ They frequently moved localities and focused entirely on a new 'straight life' that would not cross paths with the Sistema or with those who had been in their lives prior to their imprisonment. This trajectory of disappearance was taken mostly by those seeking to escape not only the authorities' view but also the vengeance of their (deadly) victims' families. Wilfredo's mother, for instance, moved towns and he joined her upon his release from prison. At a significant distance from his birth town, he focused entirely on his university education, and did not tell anybody of his past. When I asked him if he would really never tell anyone, he noted that, 'I wouldn't even tell a girlfriend'. Even though he participated in the former prisoner radio show and activities at the courthouse, he kept these post-release activities strictly separated from the rest of his life, specifically from the spaces he was using to rebuild his life on the outside, like his home and his university.

Perhaps most dramatically, one of my key research collaborators, Javi, emigrated to Spain to break with his past and the Sistema. As we knew each other from inside prison and he felt safely out of reach there, we shared multiple long conversations about life both inside and outside of prison via WhatsApp once he crossed the ocean - conversations in which he gradually felt safe enough to speak openly about the extralegal workings of the Sistema, but in which he nevertheless always omitted the reasons for his own imprisonment. The latter was significant, because although the former prisoners who manage to disappear from the authorities' view are the ones who become practically invisible to its grip, they are nevertheless those who impose the strictest of self-censoring measures on themselves, their discourses and their movement. In many ways, disappearing involved not just physical invisibility, but also a discursive transformation. This was something that many other former prisoners who did not entirely disappear also engaged in, albeit in less radical ways.

\section{Restraint: la mira, self-censorship and the dangers of exposure}

For many former prisoners, attempting to blend in and keep a low profile from the moment of release onwards was their key strategy for averting repeated encounters with the Sistema. They restricted their movement as much as possible so as not to run the risk of being caught 'de puro aire' (for nothing). In this sense, their knowledge of the weight of law enforcement also informed their fear of other people's color. In a discussion with two former prisoners called Wiz and Joey about the difficulties of post-release life one evening after we spoke on the radio show, I openly wondered why former prisoners did not self-organize outside prison as they did inside it to help each other out with basic needs.

'Loco, what I don't understand sometimes is how despite the increasing level of incarceration, the overcrowding, and the systemic maltreatment of prisoners, there are no former prisoner initiatives, associations, or cooperatives', I say over dinner after a radio show. Wiz and Joey agree, laughing, 'we're like the only ones!' Yet then 
they explain the absence of more articulated former prisoner self-organization in the light of its dangers.

'It'd be dangerous, you can't [organize],' Wiz says, 'it'd be just to arrest us, after all we're all in their view...'

'Yeah, Joey adds, 'we're aware that we all leave [prison] badly stigmatized, and the thing is, how do we wash away that stigma? Just by keeping our heads down, that's the way things are.'

One thing all former prisoners agreed on: speaking up against the stigmatization they face, against prison and police violence (or for prisoner and human rights, as they did on my radio show), could expose one's color, place one in view, and hence increase one's chances of being harassed and/or reimprisoned. It was no coincidence that the programme I organized with former prisoners ended up being a radio rather than a television programme, guaranteeing the (relative) anonymity of the speakers. Similarly, the former prisoners clearly made an effort not to talk negatively about the police or guards on the air (although this did happen occasionally, and almost always during the continuations of discussion after the radio show). Later, from his safe distance across the ocean, Javi would tell me something that made me attentive to the relation between the workings of public secrecy ${ }^{10}$ surrounding extralegal governance practices inside prison and outside of it:

The government wants to make things look a particular way [i.e. pretends to show how prison works], but it's not like that, and we know it. The problem is that if you don't want trouble, you have to keep quiet. ${ }^{11}$

In fact, as I coordinated the radio show initiative with my research collaborators, I found out the hard way that my research collaborators were right to be highly vigilant of their presence in the authorities' view. I was able to secure airtime for my radio show with a local 'urban juvenile' radio station through and with Nilson, a former gang leader whom I had known for a number of years. He was a youth organizer and a volunteer for the local Police Direction for Juvenile Affairs (DAJUV by its Spanish acronym) who aired a popular weekly two-hour music and talk show on a local radio station, and facilitated my obtaining airtime on it too. His radio programme had broad appeal to a young audience and provided a platform through which to clarify prejudices and stereotypes about prison life and post-prison stigmatization. Yet Nilson's relation to the local authorities proved not to be unproblematic. Even though all of my research collaborators who spoke on this show, which was entirely voluntary, were aware of this (and adjusted their narratives where they deemed necessary), there was a lingering sense of danger around the potential repercussions that revelations (be these of the speakers' identities or of prison practices) could have. Attempting to discuss issues that we considered important, it became clear that we effectively placed ourselves in the authorities' view due to the fact that we walked a very fine line between keeping and exposing the public secrets surrounding prison life - secrets as seemingly small as confirming conditions of overcrowding and as seemingly big as alluding to beatings or the 
prison drug trade. An incident that occurred while former prisoner Beto spoke about police harassment underlined this. At the time, Beto had already been out of prison for five years, yet his post-release experience of continued harassment and a (minor) incident that occurred as we were live on air reflect the 'tightness' - both the more clearly repressive and the more insidious qualities - of the transcarceral grip.

\section{Beto and the reach of the Sistema}

When I went to visit Beto the afternoon before one of the radio shows, we joked about how life twists and turns. I told him about the radio show and invited him to come along downtown that night. I knew Beto had had trouble finding steady employment and had been let go from his job as a driver for a local NGO when they found out he had been in prison. Maybe he could discuss the way the prisoner stigma follows former prisoners around even years after release? Beto said he could talk about a lot of things, but appeared hesitant about coming on the show. He complained that aside from the difficulties finding a job, he continued to have his fair share of trouble with the police:

I've been arrested about eight times since I got out. Last time they had me spend ten days at the police jail. It's like every time something happens in the neighbourhood I'm the first one they look at. Someone was assaulted? 'It must've been Beto', and vrrrm comes the police pulling up to my mom's house. Even if they know it wasn't me, they think I can tell them who did do it. Like I would know anything now. 'I don't have shit to tell them', is what I say.

Beto had been a gang member and he continued to enjoy a reputation in his barrio. In particular, when he drank, which he confessed he used to do in the classic binge fashion, his self-proclaimed bad temper would inevitably get him into trouble. 'I don't do drugs or drink hard liquor anymore though', he said to me that night, rubbing his belly. 'It's bad for me, and I have this little guy to think about now', he said, tickling his ten-month old son, whom he proudly held on the seat of the motorcycle parked outside of the house.

Beto was not entirely sure if his last stint at the police station had been resolved or not. Even though the radio show was not directly a DAJUV show, Beto reasoned that officers could still be tuned in due to Nilson's affiliation to the DAJUV, and he said, 'no quiero agarrar color' (I don't want to take on color). In other words, he did not want to be known as someone who broke the code of public secrecy, which would put him in the vice of the transcarceral grip - he was afraid there could be repercussions in the form of harassment. Understanding his doubts, I told Beto to think about it for a future time as he sorted out his pending police issues. 'Maybe you can just call in to the show anonymously rather than go?' I offered before leaving for the show. 'It would be great if someday you could give a shout out to all the guys still stuck in the penitentiary.'

Yet rather than call in anonymously, Beto ended up coming to the radio show that same night. He drove up on his motorcycle and surprised us - Wilfredo, Nilson 
and me - about fifteen minutes into our airtime. Police harassment was the first thing Beto started talking about, shielded by the promise of anonymity. Just like every show, Nilson took live calls to the station, read out texts coming in on his phone, and honoured song requests. A text came in from the penitentiary soon enough, egging Beto on. Then another text came. Nilson read it out: 'Hey is that "Beto"? Tell him "Carmelo" says hi'. He then giggled, 'ay, it appears you have an enamorado (someone in love with you)! Beto laughed sheepishly in response. I was furious. It was not a flirtatious text. Though having an enamorado literally means having someone in love with you, it is also used as slang for having a cop stuck on your case. Not only had Nilson just outed Beto on air using his real nickname, the text was also from a police officer whom Beto knew all too well. It was one of the officers who regularly harassed him. As Nilson aired the next music request, Beto excused himself. We left the cabin together and peaked out of the radio station's window to make sure 'Carmelo' was not outside in a patrol car. In those few seconds, sharing his experiences on the radio, Beto's life could have taken a turn for the worse. Stepping into the street with him, I apologised profusely. Beto, keeping his calm, put on his helmet and said, 'Anytime Yuli, I'm glad you always remember us, you know - don't give that piece of shit [Nilson] too much mind!' He then sped off into the night.

Thankfully, Beto was not arrested after the show, or in any other way affected by his participation. Having said that, even if the incident may seem small, it is part of a systemic effort on the part of the authorities to surveil, warn and punish those who threaten to reveal the Sistema's public secrets. It clearly demonstrated the lengths to which the Sistema will go to disqualify and silence the narratives of former prisoners by enforcing the code of public secrecy. It also presented an ethical dilemma, however, as it made clear that trying to create an audience for experiences of prison and stigmatization effectively puts the interlocutors (that is, former prisoners) directly in the view of the authorities, despite all the precautions taken to anonymize them. By speaking up, even if not directly or in detail about practices veiled by public secrecy, they broke an imposed code of silence, which put them into the authorities' view, and thus subjected them to the potential effects of the Sistema's transcarceral grip. 'It's too dangerous', Wiz had said. After this encounter with the police's view, or omnipresent ear, Wiz's words echoed in my head. The text directed at Beto attested not only to the reach of this transcarceral grip but also to its tightness: the closer to the surface, the more in the face of the police, the tighter its grip could be felt.

\section{Refusing the grip: the paradox of delinquent freedoms}

While many former prisoners practised restraint and patrolled the boundaries of their newly found freedom to stay out of la mira (at least most of the time), some of them (simultaneously) engaged in practices of release and refusal. By 'release', I refer to the active search for situations and relations geared at both symbolically and practically confronting the transcarceral grip and the confined or restrained 
freedoms that it produces. These practices could include using drugs (most often smoking weed), engaging in fights or (temporarily) engaging in criminal activities. Refusal, however, takes release a step further and indicates an embrace of one's stigmatized presence - whether willingly or grudgingly, rejecting presupposed social norms. In other words, refusal entailed the pursuit of a certain freedom through the (continued) engagement in crime. Posing a dilemma of a different kind, I noticed that my struggle to grapple with many of my research collaborators' practices of release and refusal - their taking of 'delinquent freedoms' - resembled the struggle that many ethnographers have had pushing through the complexity of 'delinquency' and 'criminalizing states' with a critical vocabulary (Rosas 2012: 118-119; see also Bourgois [1996] 2003; O’Neill 2015).

Entangling freedom and prison - freedom in the face of probable reimprisonment - some of my research collaborators mixed (imagined) restraint with illegal enterprise. Wiz and Norbin, for instance, both noted that they needed to smoke weed to stay sane. In this way, they framed the delinquent freedom they took to smoke weed as a mechanism to stay on the straight end of post-release life. As Wiz put it:

When I get up I roll a joint and I get up early, around 5 a.m. After I've smoked I go easy, I sweep the patio, give the dogs their food, help out my mom. Around noon I have another [joint], and in the afternoon one more... and of course before I go to bed, ha-ha. ... It helps me relax, to stay inside [the house]. When I smoke I don't get myself in trouble. ${ }^{12}$

Yet beyond the release to be found in the quotidian consumption of illegal(ized) substances, some of my other research collaborators walked paths more deeply steeped in illegal enterprise - even if their first intentions upon release were for a 'straight life'. Araña's post-release trajectory and subsequent reimprisonment illustrates this paradox of refusal and the embrace of delinquent freedom in the face of the (trans)carceral grip.

\section{Araña and the weight of the Sistema}

'When I get out... I have a plan for when I get out', Araña had said when he was still in prison. ${ }^{13}$ At the time, we were sitting in the back of the room at the community centre. He had just claimed that he 'retired' from drug trafficking shortly after starting to attend the community centre over six months earlier. Leaning in, he explained his post-release plan in a hushed voice. 'I have two guns buried, you know, I'm gonna sell them. Then I'm gonna use that money to help my mom set up a shop, to get ahead.' Through initially illegal means, Araña planned to set up a legal economic initiative when he got out of prison. As he struggled to envision a straight life for himself, most of our conversations leading up to and following his release hinged on the (equally subtle and pronounced) awareness of alternative employabilities and possible extralegal means through which visions of a legal future might be achieved. A couple of days later we came back to the conversation 
and he would tell me that he was well aware that his old work was just a phone call away. 'It's going to be up to me to take that call or not. I know I will have to be strong.' After all, the economic benefits of the drug trade have 'seduced me before and could pull me in again'. Months later, a few weeks after his release, we chatted about freedom over WhatsApp.

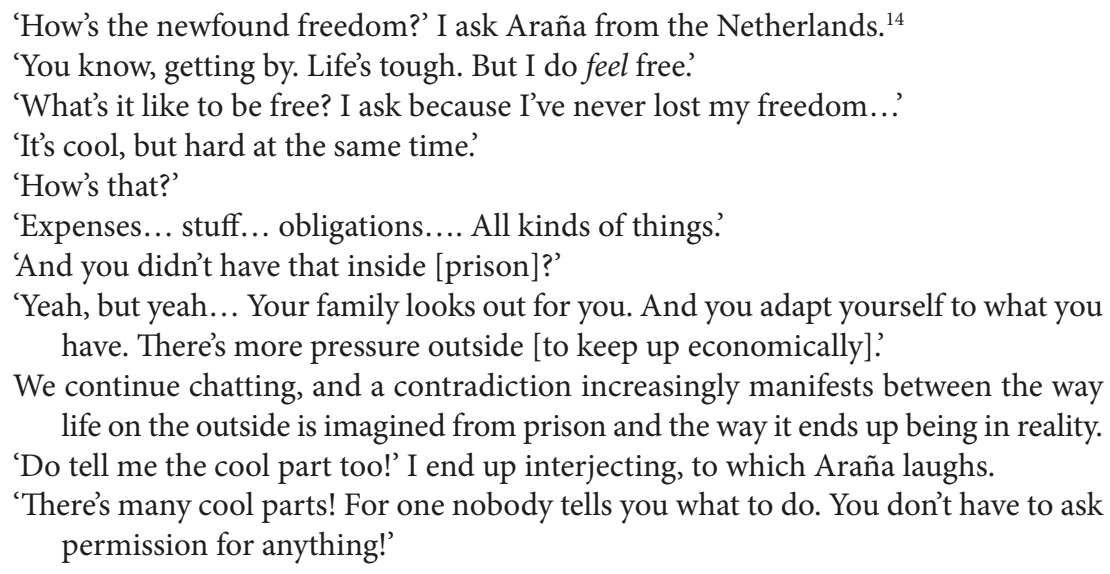

As we continued to talk over the next months, pictures of a small shop came to grace his Facebook page. Araña appeared well dressed, sporting new hip-hop style clothes, colourful snapback caps and silver chains. He was rapping and recorded his first songs, but he did not go back to school as he had planned while in prison. Then there was a car in his pictures. He posed with it and drove it. I began worrying whether he had taken 'the call' and decided to ask him if it was his. He pushed back, 'Why does everyone assume that when something's in your pictures it's suddenly yours?' I refrained from asking about it again and most of our conversations revolved around rap music. But I began to suspect that for Araña, the possibility or reality of a straight life and the possibility or reality of drug trafficking co-existed rather than stood in opposition one to the other.

For Araña, as for other former prisoners, once outside prison, law-abiding and law-breaking practices continued to manifest as 'different (meaning parallel, rather than past) parts' of their life (O'Neill 2015: 42). In the same breath that Araña would describe himself as humble, he would assure me that he was sobre (on top of things) - vago pero firme (a stand-up thug). A constant slippage appeared to exist between his projection of a straight life and the delinquent freedoms he took. We hardly ever explicitly spoke of his involvement in drug trafficking. Was it to present to me the part of his life that he had cultivated so arduously in prison? Or was it his own attempt to keep potential (re)imprisonment and freedom separated? There were cues, like particular gang signs, that I took as entry points for my attempts to start a conversation about his delinquent engagements. He would laugh, shake his head and call me bandida, drawing on a mutual understanding of what was going on - 'you know it' - yet never make his involvement verbally explicit. 
A little over a year after his release, it was reported that the police had rounded up a drug cartel and Araña was reimprisoned for drug trafficking. Between two properties rented in the city, the police confiscated a pick-up truck, a regular car (that car), a motorcycle, two handguns and 22 kilos of marijuana. Mugshots of Araña and his associates, taken close-up as they sat or stood cuffed against a wall, were run across the local news. While this type of mediated representation is typical, it brought my research to a painful full circle, as I previously wrote about these kinds of representations (Weegels 2018a). On his mugshot, Araña's eyes were bloodshot and wide, his face sweaty, his hair tousled. The pockets of his jeans stuck inside out from his side, the studs in his ears protruded as if they were undone. His slightly pulled up T-shirt revealed not only his undershirt but also showed that he was made to sit down on the ground with his wrist cuffed to someone standing above him, outside of the frame. Looking up at the camera instead of straight into it, his position was one of subjection. Ironically, the news slogan Sin Censura (without censorship) was stamped across the lower part of the pictures' frames. Unintentionally, it alluded to Araña's failed attempt at self-censorship as his parallel worlds publicly collided.

Araña's reimprisonment pushed me to think about whether he had ever really been free from the Sistema's legal or extralegal effects, much like Bobby noted about his time done 'for the System'. However, it also points to the paradox of refusal. While refusal appears to (temporarily) deny the effects of the transcarceral grip through its denial of the law, it also appears to subject former prisoners to a potentially heavier grip once caught. Embracing a very personal search for respect, Araña's year outside prison was geared at preventing further intervention in his life. He did what he wanted, 'without asking for permission'. What is more, he demanded respect by using his color and his prison time to his advantage, seeking to construct a life outside of poverty for his family on his own account through both legal avenues (music) and illegal avenues (drug trafficking). The delinquent freedoms he took, however, eventually subjected him to a heavy-handed intervention that pulled him back to prison, where he has expressed that he faces a tighter grip than before. ${ }^{15} \mathrm{He}$ is no longer allowed out to the community centre, and was recently transferred to a formal penitentiary facing a multiple-year sentence.

\section{Conclusion}

The multiplicity of layers that my research collaborators' post-release trajectories reveal is intimately related to the expansion of the Nicaraguan carceral state. It must be noted that the Sistema's transcarceral grip is present in all trajectories, despite the intentions to curb or avert it as much as possible. The tightness with which its grip envelops them, however, and the weight with which it (re)impinges itself on their lives, varies across the trajectories. An attention to this subject level of carceral expansion allows for a fine-grained understanding of the Sistema's disciplinary power without losing sight of the wider power dynamics at work. Particularly, it allows us to expand our understanding of those subjected to the logics of a (hybrid) carceral 
state, but also to why not everybody is affected by its surveillance or disciplinary power in the same way. While there is definitely an overlap here (all of my research participants were part of geographically marginalized communities which tend to be subjected to the state's carceral apparatus more than others), they were kept in view and acted upon as former prisoners, as fichados, in particularly pervasive ways - not only by state authorities, but by the party-state's full hybrid surveillance system (including the governing party's Citizen Power Councils and voluntary police).

While delinquent stigmas that are gendered, classed and racialized in particular ways then serve to frame any citizen who fits the delinquent stereotype as a carceral subject (Brown 2014), I suggest that it is being in the vice of transcarceral grip that is decisive in determining who exactly is acted upon and who is not. Thinking about Wiz and his weed, or Beto and his drunken fights, or Araña and his drug trafficking, and their simultaneous (parallel) appearances as victims and perpetrators, delinquents and 'changed men', urges for a fluid understanding of the trajectories across which individuals may move by alternately engaging in (degrees of) refusal and (degrees of) self-censorship. Much in the way that the ongoing surveillance of carceral subjects has been held to produce 'fugitive life' (Goffman 2014) in the United States, then, it produces particular modalities of self-censorship and refusal, release and restraint, in Nicaragua. While former prisoners' self-censoring practices point to the confined character that freedom can take on, the delinquent freedoms that they (simultaneously) begin to take against the continued impingement of law enforcement on their lives reveals an entanglement - 'parallel rather than past' (O'Neill 2015: 42) - that relates back to prison, pointing to the expansion of Nicaragua's hybrid carceral system. Following from this, the long reach of the Sistema by way of its transcarceral grip - which is enforced both legally and extralegally, and includes the code of silence it imposes through public secrecy - points to the pervasiveness of disciplinary power and its lingering capacity for (violent) repression. A wider attention for carceral states' lasting hold over its subjects should then better attune us to both former prisoners' continuing experiences of (hybrid) disciplinary power and the obstacles that the development of transcarceral mechanisms of control pose for prisoner re-entry.

\section{Acknowledgements}

I am deeply grateful to all those young men whose lives I was let into, both inside and outside prison in Nicaragua. In particular, I thank Araña, who was reimprisoned as I finished writing the Ph.D. thesis chapter that this article is based on, and dedicate this article to the memory of Beto, who recently died in a workrelated accident in Mexico - where he had migrated to better provide for his family. The research presented here was carried out with the help of the Centre for Latin American Research and Documentation (CEDLA) and the Amsterdam Institute for Social Science Research (AISSR). Many thanks to the reviewers and editors for their keen eye and inspiring ideas, which much helped to improve this article. 
Trained as an anthropologist, Julienne Weegels (ORCID: https://orcid.org/0000-00017988-9903) conducted a multi-sited prison ethnography in Nicaragua between 2009 and 2016. Her research centres around (former) prisoners' experiences of prison governance arrangements (both legal and extralegal), violence, stigmatization and the hybrid state - both inside and outside prison. She has published in a number of peer-reviewed journals, including the Journal for Latin American Studies and Oxford Development Studies Journal, about the politics of policing, exclusion and mediated representation of criminalized youth.

\section{Notes}

1. Private interview in Managua, April 2015. All names used are pseudonyms. To safeguard the anonymity of my participants I do not mention the geographical location of the prisons where I conducted research, with the exception of La Modelo prison, located outside the capital city, as I did not conduct research inside that prison (and so many prisoners enter and leave it that it would arguably be very difficult for authorities to know exactly who I spoke to).

2. After I left Nicaragua in 2016, I remained in touch with a number of my research collaborators, of which some interactions are reflected here. Inside prison, my research collaborators were largely part of a theatre in prison programme that was set up and taught by my husband, a Nicaraguan national and theatre director. The programme ran at a regional penitentiary between 2009 and 2013 and at a community centre to which prisoners from a local city police jail were bused every weekday between 2015 and 2016 . We were mostly present at the facilities together and spent between two and five days per week with the prisoners for at least three and up to seven hours per day. Over time I followed research collaborators from both sites into their post-release lives.

3. This changed radically after April 2018, when the full-scale deployment of this hybrid carceral system to repress massive anti-government protests pushed its existence into the spotlight. During the repression, specifically 'Operation Clean-Up', the Nicaraguan National Police overtly collaborated with armed para-state groups pertaining to the governing political party (the FSLN, Sandinista National Liberation Front) to violently quash the protests, and subsequently deployed its legal system to process the protesters for 'terrorism' (see Weegels 2018b). In the process, over three hundred protesters were killed and more than eight hundred have been imprisoned (InterAmerican Commission on Human Rights, IACHR 2018).

4. Wacquant notes that 'a brutal swing from the social to the penal management of poverty', combined with a 'punitive revamping' of public policy concerning urban marginality, established a 'single carceral continuum' between the ghetto and the prison (Wacquant 2000: 384).

5. Private interview in Managua, April 2015.

6. Such as those participating in crime prevention committees (CPSDs) or neighbourhood councils (CPCs or Consejos Familiares).

7. I also tended to meet more in such public places with former prisoners whose homes I did get to know. This was at least in part because these were the places in which we would engage in joint activities, like preparation for the radio show and discussions after it, but also where we could (paradoxically) engage in more private conversations about their lived experience.

8. There were two 'groups' of prisoners that I did not or could not follow to the outside. The first consists of prisoners who break all connections to their life inside prison, including with me. For hem, having me in their lives would be a continuation of a connection to their prison experiences and/or a potential liability as people might ask, 'How does this guy know that foreign girl?' The second consists of prisoners whom I perceived to be too dangerous to be in contact with on the outside in terms of my own safety, which I realize is a highly subjective judgement, but nonetheless relevant.

9. Group conversation, December 2015. 
10. I understand public secrets along the lines of Michael Taussig's work on public secrecy and defacement, as secrets that are in fact 'shared and known but unspoken' (1999: 50). This produces tensions among those interested in the maintenance and/or rupture of the prison system's general culture of institutional(ized) public secrecy, which tend to be expressed in the (extralegal) use of violence (e.g. Penglase 2014, Weegels 2019).

11. Private conversation, September 2016.

12. Private conversation, 2017.

13. From field notes, October 2015.

14. Private conversation, July 2016.

15. Private conversation, November 2017.

\section{References}

Allspach, A. 2010. 'Landscapes of (Neo-)Liberal Control: The Transcarceral Spaces of Federally Sentenced Women in Canada'. Gender, Place \& Culture 17 (6): 705-723. doi:10.1080/0966369X.2010.517021.

Antillano, A. 2017. 'When Prisoners Make the Prison: Self-Rule in Venezuelan Prisons'. Prison Service Journal 229: 26-30.

Arias, E. D. 2006. 'The Dynamics of Criminal Governance: Networks and Social Order in Rio de Janeiro'. Journal of Latin American Studies 38 (2): 293-325. doi:10.1017/ S0022216X06000721.

Biondi, K. 2016. Sharing this Walk: An Ethnography of Prison Life and the PCC in Brazil. Chapel Hill: University of North Carolina Press.

Bourgois, P. (1996) 2003. In Search of Respect: Selling Crack in El Barrio. 2nd edition. Cambridge: Cambridge University Press.

Brown, M. 2014. 'Visual Criminology and Carceral Studies: Counter-Images in the Carceral Age'. Theoretical Criminology 18 (2): 176-197. doi:10.1177/1362480613508426.

Carter, J. H. 2017. 'Mass Incarceration, Co-Governance, and Prison Reform in Honduras'. NACLA Report on the Americas 49 (3): 354-359. doi:10.1080/10714839.2017.1373965.

Crewe, B. 2011. 'Depth, Weight, Tightness: Revisiting the Pains of Imprisonment'. Punishment \& Society 13 (5): 509-529. doi:10.1177/1462474511422172.

Darke, S. and C. Garces. 2017. 'Surviving in the New Mass Carceral Zone'. Prison Service Journal 229: 2-9. https://ssrn.com/abstract=2893022.

Denyer Willis, G. 2015. The Killing Consensus: Police, Organized Crime, and the Regulation of Life and Death in Urban Brazil. Berkeley: University of California Press.

Fassin, D. 2013. Enforcing Order: An Ethnography of Urban Policing. Cambridge: Polity Press.

Foucault, M. (1975) 1991. Discipline and Punish: The Birth of the Prison. London: Penguin Books.

Garland, D. 1997. "'Governmentality” and the Problem of Crime: Foucault, Criminology, Sociology'. Theoretical Criminology 1 (2): 173-214. doi:10.1177/1362480697001002002.

Garland, D. 2013. 'Penality and the Penal State'. Criminology 51 (3): 475-517. doi:10.1111/1745-9125.12015.

Gledhill, J. 2015. The New War on the Poor: The Production of Insecurity in Latin America. London: Zed Books.

Goffman, A. 2014. On the Run: Fugitive Life in an American City. Chicago: University of Chicago Press.

Goffman, E. (1961) 1991. Asylums: Essays on the Social Situation of Mental Patients and Other Inmates. London: Penguin Books. 
Goldstein, D. M. 2012. Outlawed: Between Security and Rights in a Bolivian City. Durham, NC: Duke University Press.

Holston, J. 2008. Insurgent Citizenship: Disjunctions of Democracy and Modernity in Brazil. Princeton, NJ: Princeton University Press.

Huggins, M. K. (ed.). 1991. Vigilantism and the State in Modern Latin America: Essays on Extralegal Violence. New York: Praeger.

Inter-American Commission on Human Rights (IACHR). 2018. 'Serious Human Rights Violations in the Context of Social Protests in Nicaragua'. https://www.oas.org/en/ iachr/reports/pdfs/Nicaragua2018-en.pdf, last accessed 2 March 2020

Iturralde, M. 2016. 'Colombian Prisons as a Core Institution of Authoritarian Liberalism'. Crime, Law and Social Change 65: 137-162. doi:10.1007/s10611-015-9581-7.

Jaffe, R. 2013. 'The Hybrid State: Crime and Citizenship in Urban Jamaica'. American Ethnologist 40 (4): 734-748.

Jensen, S. 2010. 'The Security and Development Nexus in Cape Town: War on Gangs, Counterinsurgency and Citizenship'. Security Dialogue 41 (1): 77-97. doi:10.1177/ 0967010609357038.

Macaulay, F. 2013. 'Modes of Prison Administration, Control and Governmentality in Latin America: Adoption, Adaptation and Hybridity'. Conflict, Security \& Development 13 (4): 361-392. doi:10.1080/14678802.2013.834114.

Maruna, S. 2001. Making Good: How Ex-Convicts Reform and Rebuild their Lives. Washington, DC: American Psychological Association.

Moran, D. 2014. 'Leaving Behind the "Total Institution"? Teeth, Transcarceral Spaces and (Re)Inscription of the Formerly Incarcerated Body'. Gender, Place \& Culture 21 (1): 35-51. doi:10.1080/0966369X.2012.759906.

O’Neill, K. L. 2015. Secure the Soul: Christian Piety and Gang Prevention in Guatemala. Berkeley: University of California Press.

Penglase, B. 2014. Living with Insecurity in a Brazilian Favela: Urban Violence and Daily Life. New Brunswick: Rutgers University Press.

Rodgers, D. 2006. 'The State as a Gang: Conceptualizing the Governmentality of Violence in Contemporary Nicaragua. Critique of Anthropology 26 (3): 315-330. doi:10.1177/ $0308275 X 06066577$.

Rosas, G. 2012. Barrio Libre: Criminalizing States and Delinquent Refusals of the New Frontier. Durham, NC: Duke University Press.

Sim, J. 2009. Punishment and Prisons: Power and the Carceral State. London: SAGE Publications.

Taussig, M. 1999. Defacement: Public Secrecy and the Labor of the Negative. Stanford, CA: Stanford University Press.

Van Stapele, N. 2016. "We are not Kenyans": Extra-judicial Killings, Manhood and Citizenship in Mathare, a Nairobi Ghetto'. Conflict, Security \& Development 16 (4): 301-325.

Ugelvik, T. 2014. Power and Resistance in Prison: Doing Time, Doing Freedom. London: Palgrave Macmillan.

Wacquant, L. 2000. 'The New "Peculiar Institution": On the Prison as Surrogate Ghetto' Theoretical Criminology 4 (3): 377-389. doi:10.1177/1362480600004003007.

Wacquant, L. 2009. Prisons of Poverty. Minneapolis: University of Minnesota Press. 
Weegels, J. 2017. 'Prisoner Self-Governance and Survival in a Nicaraguan City Police Jail'. Prison Service Journal 229: 15-18.

Weegels, J. 2018a. “The Terror and Scourge of the Barrio": Representations of Youth Crime and Policing on Nicaraguan Televised News'. Journal of Latin American Studies 50 (4): 861-887. doi:10.1014/S0022216X18000317.

Weegels, J. 2018b. 'Inside Out: Confinement, Revolt and Repression in Nicaragua'. Journal of Political and Legal Anthropology [Speaking Justice to Power Series]. https:// politicalandlegalanthro.org/2018/10/03/inside-out-confinement-revolt-andrepression-in-nicaragua/, last accessed 2 March 2020.

Weegels, J. 2019. 'Prison Riots in Nicaragua: Negotiating Co-Governance Amid Creative Violence and Public Secrecy'. International Criminal Justice Review. doi:10.1177/ 1057567719849485. 